\title{
Inhibitory Effects of Heavy Metals on Cytochrome P4501A Induction in Permanent Fish Hepatoma Cells
}

\author{
B. J. Brüschweiler'*, F. E. Würgler', K. Fent' \\ 1 Swiss Federal Institute for Environmental Science and Technology (EAWAG) and Swiss Federal Institute of Technology (ETH). Cberlandstrasse \\ 133. CH-8600 Dübendorf, Switzerland \\ : Institute of Toxicology, Swiss Federal Institute of Technology and Lniversity of Zürich. Schorenstrasse 16. CH-860)3 Schwerzenbach. Switzerland
}

Received: 20 December 1995/Revised: 6 May 1996

\begin{abstract}
The interactions in vitro of heavy uutals $\mathrm{Cd}(\mathrm{II})$. $\mathrm{Co}(\mathrm{II}), \mathrm{Cu}(\mathrm{II}), \mathrm{Ni}(\mathrm{II}), \mathrm{Pb}(\mathrm{II})$, and $\mathrm{Zn}(\mathrm{II})$ with cytochrome P4501 A (CYP1A) induction response and enzyme activity were studied in fish hepatoma cells PLHC-1. Cells were simultaneously exposed to heavy metals and to 3-methylcholanthrene (3-MC), an inducer of CYPIA. Heavy metals were added to the cells in different concentrations. Cytotoxicity were measured in the neutral red (NR) assay, relative CYPIA protein contents in an enzyme-linked immunosorbent assa) (ELISA), and CYPIA activities in the ethoxyresorufin- $O$-deethylase (EROD) assay. All metals had a more pronounced effect on EROD activity than on CYPIA protein content and cytotoxicity. For the most active metal $\mathrm{Cd}(\mathrm{II})$, a $50 \%$ inhibition of EROD activity was observed at significantly lower concentrations $\left(2.2 \cdot 10^{-5} \mathrm{M}\right)$ than a $50 \%$ reduction of CYPIA protein $\left(5.3 \cdot 10^{-5} \mathrm{M}\right)$, and a $50 \%$ cytotoxicity $\left(1.4 \cdot 10^{-4} \mathrm{M}\right)$. The inhibitory potency of the metals had the following order: $\mathrm{Cd}(\mathrm{II})>\mathrm{Ni}(\mathrm{II})>\mathrm{Cu}(\mathrm{II})>$ $\mathrm{Co}(\mathrm{II})=\mathrm{Zn}(\mathrm{II})>\mathrm{Pb}(\mathrm{II})$. In a second set of experiments, lysates of 3-MC-induced cells were exposed to heavy metals. $\mathrm{Cd}$ (II) and $\mathrm{Cu}$ (II) caused a 50\% inhibition of EROD activity at significantly lower concentrations than in the experiments with living cells, at $8.2 \cdot 10^{-6} \mathrm{M}$ and $1.3 \cdot 10^{-5} \mathrm{M}$. respectively. whereas the effect by $\mathrm{Co}(\mathrm{II})$ occurred at a significantly higher concentration $\left(8.2 \cdot 10^{-4} \mathrm{M}\right)$. The results indicate that $\mathrm{Cd}(\mathrm{II})$ and $\mathrm{Cu}(\mathrm{II})$ in particular may affect the CYPIA system of the liver of fish at low concentrations through direct inhibition of the CYP1A enzyme activity. CYPIA induction response in fish liver is increasingly being used in biomonitoring programs. In the environment, interactions of CYPIA-inducing and CYPIAinhibiting components (such as heavy metals) can be expected and must be taken into consideration.
\end{abstract}

Correspondence to: K. Fent

*Prescit aduress: Lniversity of Connecticut. Storrs. Connecticut 06268 . USA
Heavy metals are widespread and persistent in the aquatic environment. accumulate and show various adverse effects in fish (Sorensen 1991) and other aquatic organisms (Mance 1987). Several mechanisms that may account for their toxicity at the cellular level have been described (Viarengo 1989). Particularly. interactions between heavy metals and $\mathrm{SH}$-containing proteins that may affect their function. thus compromising several enzyme activities (Viarengo and Nicotera 1991). Metals such as $\mathrm{Cd}(\mathrm{II}), \mathrm{Cu}(\mathrm{II})$, and $\mathrm{Pb}(\mathrm{II})$ are known to inhibit the cytochrome P450 enzyme activities (Alvares et al. 1972; Hadley et al. 1974) and to reduce the microsomal cytochrome P450 content (De Matteis 1978) in mammals. This may be relevant for the metabolism of xenobiotics and endogenous substrates in fish. in which several cytochrome P450 subfamilies have been described (Stegeman and Hahn 1994). Cytochrome P4501 A (CYPIA) is induced by various polycyclic aromatic hydrocarbons re.g.. benzo $[a]$ pyrene) and halogenated aromatic hydrocarbons (e.g.. 2.3.7.8-tetrachlorodibenzo-p-dioxin. 3.3'.4.4' -tetrachlorobiphenyl) mainly in fish liver, but other organs as well. Induction of CYPIA is increasingly being used as biomarker for such compounds in fish liver (Bucheli and Fent 1995) and for assessing the induction potential of environmental samples in vitro (Tillitt et al. 1991). To our knowledge, Cd(II) is the only heavy metal that has been reported to inhibit CYPIA in fish (Fair 1986: Förlin et al. 1986: George and Young 1986). Inhibition of CYPIA induction response has been observed after intraperitoneal co-administration of $\mathrm{Cd}(\mathrm{II})$ and a CYPIA-inducer in fish (Fair 1986: George and Young 1986). This inhibition appears to be dependent upon time (George and Young 1986). route of administration (Förlin et al. 1986), and dose (George 1989).

Several mechanisms may be responsible for the effects of metals on the CYPIA system. Cd(II). Co(II). Cu(II). Ni(II). $\mathrm{Pb}(\mathrm{II}), \mathrm{Zn}(\mathrm{II})$, and other metals such as $\mathrm{Hg}(\mathrm{II})$ and $\mathrm{Sn}(\mathrm{II})$ stimulate the turnover of heme by the induction of heme oxygenase accompanied by the loss of cytochrome $\mathrm{P} 450$ in vivo (Maines and Kappas 1977). Pb(II) is an inhibitor of the 5-aminolacvulinale (ALA) dehydratase. Co(II) an inhibitor of the ALA synthetase. and both $\mathrm{Pb}(\mathrm{II})$ and $\mathrm{Co}(\mathrm{II})$ inhibit the ferrochelatase (De 
Matteis 1978; Sassa 1978; Tephly 1978). Furthermore. direct inhibition of benzo[a]pyrene hydroxylase by $\mathrm{Cd}(\mathrm{II})$ in mammalian microsomes after short-time exposure has been reported at low concentrations of $10^{-h} \mathrm{M}$ and higher (Fukuhara and Takabatake 1982). Recently, Pb(II) has been found to preferentially inhibit the expression and induction of CYPIA2 enzyme at both the mRNA and the protein level in mammals (Degawa et al. 1993a). It is probable that heavy metals affect the expression of cytochrome P450 isozymes due to specific interactions with DNA-binding proteins (Degawa et al. 1993b: Goering 1993). For the above reasons. more information about the sensitivity and relevance of these mechanisms is needed. when heavy metals and CYP1A-inducers are present in fish. These effects may be important in environmental monitoring, when CYPIA is used as biomarker in heavy metal polluted waters.

The aim of this study was to investigate in vitro interactions of $\mathrm{Cd}(\mathrm{II}), \mathrm{Co}(\mathrm{II}), \mathrm{Cu}(\mathrm{II}), \mathrm{Ni}(\mathrm{II}), \mathrm{Pb}(\mathrm{II})$, and $\mathrm{Zn}$ (II) with the CYP1A system. In vitro methods are useful tools to study interactions of CYPIA-inducing and CYPIA-inhibiting compounds (Brüschweiler et al. 1996a). The permanent fish hepatoma cell line PLHC-1 is derived from topminnow (Poeciliopsis lucida) (Hightower and Renfro 1988; Ryan and Hightower 1994) showing sensitive and prompt CYP1A-induction response (Hahn et al. 1993; Brüschweiler et al. 1996b). In a first set of experiments, the effects of these metals on EROD activity, relative CYPIA protein content, and cytotoxicity were analyzed under different conditions. Effects were investigated in cultured living cells after simultaneous exposure of a CYPlA-inducer and of metals for $3 \mathrm{~d}$. In a second set of experiments, 3-MCinduced cell lysates were treated for a short period of time with different metals and the inhibition of EROD activity was measured. The latter allowed the analysis of the direct effects on the enzyme activity alone and to exclude the indirect effects. e.g., on heme metabolism or on CYPIA protein synthesis. The data obtained are compared with the available in vivo and in vitro information in fish.

\section{Materials and Methods}

\section{Chemicals}

$\mathrm{CdCl}_{3}, 3-\mathrm{MC}$, and bovine serum albumin (BSA) were obtained from Fluka AG (Buchs, $\mathrm{CH}$ ). $\mathrm{Co}\left(\mathrm{NO}_{3}\right)_{2} \cdot 6 \mathrm{H}_{2} \mathrm{O}, \mathrm{CuSO}_{4} \cdot 5 \mathrm{H}_{2} \mathrm{O}$, $\mathrm{Ni}\left(\mathrm{NO}_{3}\right)_{2} \cdot 6 \mathrm{H}_{2} \mathrm{O}, \mathrm{Pb}\left(\mathrm{NO}_{3}\right)_{2}$, and $\mathrm{ZnCl}$, were purchased from Merck (Darmstadt, D). 7-Ethoxyresorufin (7-ER) was obtained from Molecular Probes (Eugene, OR, USA). The monoclonal mouse anti-scup antibody 1-12-3 was a gift from J.J. Stegeman (Woods Hole Oceanographic Institution. USA). The peroxidase-conjugated goat anti-mouse antibody was purchased from Dako (Glostrup. Denmark). Peroxidase substrate kit and the dye reagent for the protein assay were purchased from BioRad Laboratories (Hercules. CA. USA). Other chemicals and reagents were obtained as before (Brüschweiler et al. 1995: Brüschweiler $e t$ al. 1996b).

\section{Cell Culture}

Fish hepatoma cells PLHC-I were supplied by L.E. Hightower (Lniversity of Connecticut, USA) and were grown and subcultivated as described previously ( Tahn et al. 1993: Brüschwei ar ef al. 19951. The cells were maintained as monolaver cultures at $300^{\circ} \mathrm{C}$ in a $5 \% \mathrm{CO}$ atmosphere in Eagle Minimum Essential Medium (MEM) with Earle's salts. supplemented with $\mathrm{i} 0 \%(\mathrm{v} / \mathrm{v})$ fetal calf serum (FCS), $2 \mathrm{mM} \mathrm{L-}$ glutamine. $25 \mathrm{mM}$ sodium hydrogen carbonate. 100 units $/ \mathrm{ml}$ penicillin G and $100 \mu \mathrm{g} / \mathrm{ml}$ streptomycin in $75 \mathrm{~cm}^{2}$ flasks. PLHC-1 cells $\left(8 \cdot 10^{4}\right.$ ) in $100 \mu \mathrm{l}$ medium containing $10 \%(v / v)$ FCS were seeded in wells of a 96-well tissue culture microtiter plate (Nunclon ${ }^{\text {tw }}$ ). Cells were allowed to attach. and were grown in the incubator for $24 \mathrm{~h}$ at $30^{\circ} \mathrm{C}$ and $5 \% \mathrm{CO}$ atmosphere.

\section{Treatment with 3-Methylcholanthrene and Metals}

3-Methylcholanthrene (3-MC) was dissolved in dimethyl sulfoxide (DMSO) in a concentration of $5 \mathrm{mM}$ and diluted with MEM containing $10 \%(\mathrm{v} / \mathrm{v}) \mathrm{FCS}$ to a concentration of $10^{\circ} \mathrm{M} . \mathrm{CdCl}, \mathrm{Co}\left(\mathrm{NO}_{2}\right)=6 \mathrm{H}, \mathrm{O}$. $\mathrm{CuSO}_{4} \cdot 5 \mathrm{H}_{2} \mathrm{O}, \mathrm{Ni}\left(\mathrm{NO}_{1}\right)_{2} \cdot 6 \mathrm{H}_{2} \mathrm{O}, \mathrm{Pb}\left(\mathrm{NO}_{2}\right)_{2}$ and $\mathrm{ZnCl}_{2}$ were dissolved in distilled water in a concentration of $0.5 \mathrm{M}$ and filtered through a $0.2-\mu \mathrm{m}$ filter (Schleicher \& Schuell). These metal stock solutions were stored in glass vials at $4^{\circ} \mathrm{C}$ for no longer than two weeks. To minimize the possible loss of metals by sorption to containers, glassware was approriately handled (rinsing). Concentrations of metals in this paper refer to these metal salts. and not to the free metal ion concentrations. The common following terminology was used for the metals $(\mathrm{Me}$ ) in the medium: $\mathrm{Me}(\mathrm{II})$, which is the sum of all different species of the metal with oxidation number + II.

Stock solutions were diluted with MEM containing 10\% (v/v) FCS for dilution series. When the color of the medium changed, the $\mathrm{pH}$ was adjusted to 7.4 with $0.5 \mathrm{~N} \mathrm{NaOH}$. After removal of the old medium from the wells. $50 \mu \mathrm{l}$ of the medium containing 3-MC and $50 \mu \mathrm{l}$ of medium containing metals was added to the wells and incubated at $30^{\circ} \mathrm{C}$ for $72 \mathrm{~h}$. The final concentration of $3-\mathrm{MC}$ was $5 \cdot 10^{\circ} \mathrm{M}$. which has been shown to cause maximal induction after a 3-d exposure (Brüschweiler et al. 1996b)

\section{Neutral Red Assay; ELISA, Total Proteins}

The neutral red assay (NR assay) and enzyme linked immunosorbent assay wih cells (ELISA) were performed as described previously (Brüschweiler et al. 1995, 1996b). The total protein content per well was determined using the Bio-Rad protein assay with Commassie blue dye (Brüschweiler et al. 1996b).

\section{EROD Assay}

The EROD assay was carried out as described previously (Bruschweiler et al. 1996a). By freezing and thawing. cells were lysed and the lysate used for EROD analysis. After $72 \mathrm{~h}$ exposure, the medium was removed and the plates were transferred to a freezer $\left(-80^{\circ} \mathrm{C}\right)$. After thawing plates for $10 \mathrm{~min}$ at room temperature. $20 \mu / \mathrm{BSA} 15.32 \mathrm{mg} / \mathrm{ml}$ in $50 \mathrm{mM}$ Tris. $\mathrm{pH} 7.8)$ and $40 \mu \mathrm{l} 7$-ER $(4 \mu \mathrm{M}$ in $50 \mathrm{mM}$ Tris. $\mathrm{pH} 7.8)$ were added to each well containing cell lysate. The plates were shortly shaken on a plate shaker and incubated for $15 \mathrm{~min}$ at room temperature. Afterwards. $20 \mu$ l NADPH $(6.7 \mathrm{mM}$ in $50 \mathrm{mM}$ Tris. $\mathrm{pH} 7.8)$ were addod to each well. The final reaction vo'ume was $80 \mu \mathrm{l}$ per well and linal concentrations of BSA, 7-ER, and NADPH were $1.33 \mathrm{mg} / \mathrm{ml}$. $2 \mu \mathrm{M}$, and $1.67 \mathrm{mM}$. respectively. Fluorescence was measured every $60 \mathrm{~s}$ for $15 \mathrm{~min}$ on a plate reader (Dynatech Fluorolite 1000 ) with a $530 \mathrm{~nm}$ excitation filter and a $590-\mathrm{nm}$ emission filter at a lamp voltage of $11 \mathrm{~V}$. The fluorescence data were fitted to a resorufin standard curve.

For the analysis of short-term effects of metals on EROD activity in cell lysate. cells were exposed to $3-\mathrm{MC}\left(5 \cdot 10^{\circ} \mathrm{M}\right)$ for $3 \mathrm{~d}$. Plates were transferred to a freezer and allowed to thaw for $10 \mathrm{~min}$ at room temnerature. Thereafter. cell lisates were exposed to $20 \mu \mathrm{l}$ of a series 


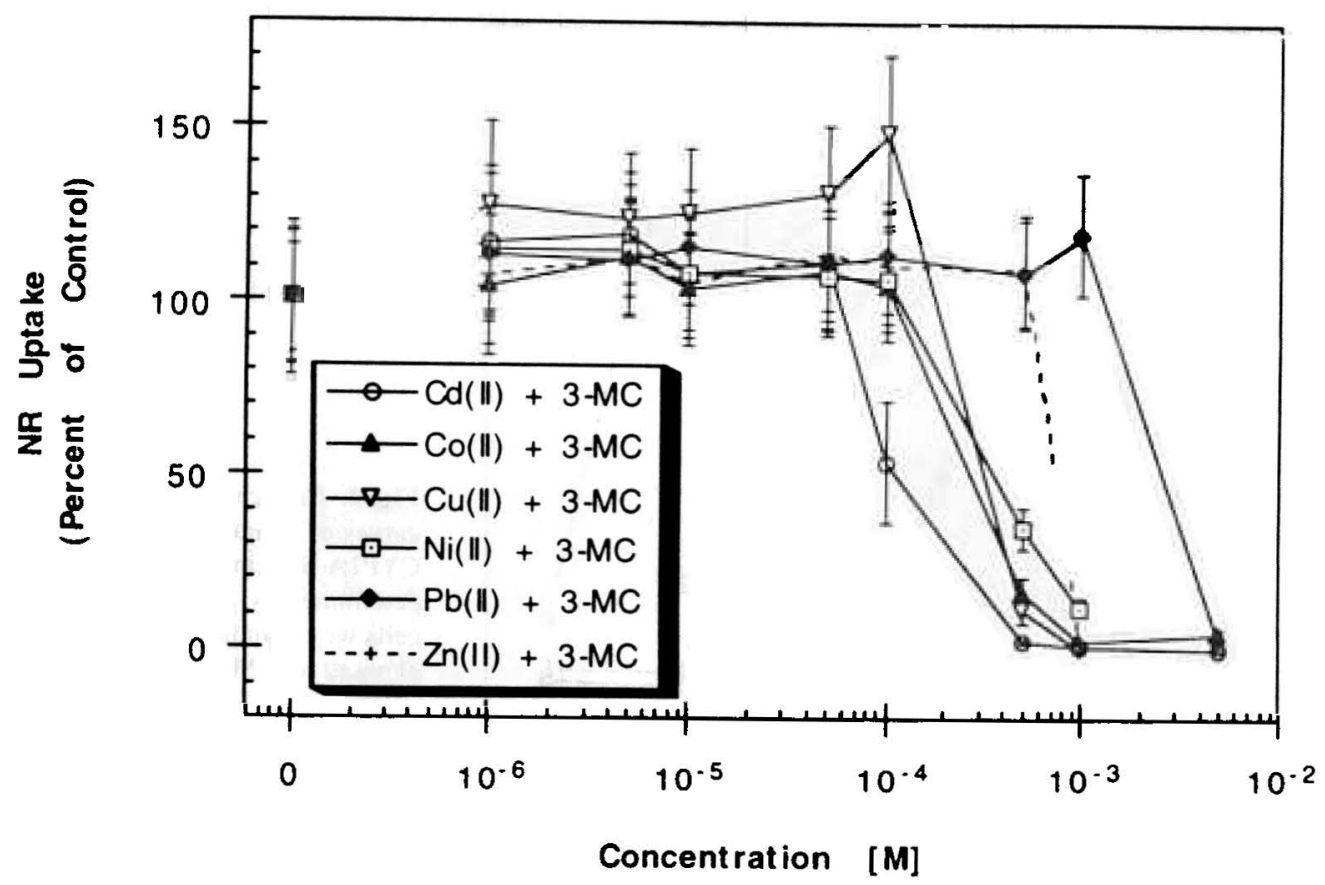

Fig. 1. Cytotoxicity of metals in PLHC-I cells. Cells were simultaneously incubated with noncytotoxic concentrations of $3-\mathrm{MC}\left(5 \cdot 10^{-5} \mathrm{M}\right)$ and a series of dilutions of metal: for $3 \mathrm{~d}$. Cytotoxicity was determined by NR uptake assay. Data are shown as mean percentage of control \pm S.E.M. (six value. $)$ of metals in Tris buffer ( $50 \mathrm{mM}$ Tris, pH 7.8), instead of BSA solution. for $15 \mathrm{~min}$ following the described protocol.

\section{Data Analysis and Statistics}

Each experiment was performed at least three times. Data in different groups were reduced to the arithmetic mean \pm standard error of the mean (S.E.M.). Concentrations, at which the enzymatic activity and the relative protein content of CYPIA as well the cytotoxicity were one-half maximal (EC50), were determined by regression analysis using a logarithmic curve fit model or a Michaelis-Menten model (Brüschweiler et al. 1995). Means of EC50 values were compared with Student's t-test with significance limits $\alpha<0.05$.

\section{Results}

\section{Simultaneous Exposure to a CYPIA-Inducer and Metals for Three Days}

Cells were simultaneously exposed to a non-cytotoxic 3-MCconcentration $\left(5 \cdot 10^{-6} \mathrm{M}\right)$ and different metals for $3 \mathrm{~d}$. Heavy metals were added to the cells in different concentrations. Cytotoxic effects were measured at similar concentrations as in earlier studies, in which metals were incubated alone for $1 \mathrm{~d}$ (Babich et al. 1986; Segner and Lenz 1993; Ryan and Hightower 1994). Figure 1 shows that the sequence of cytotoxicity is $\mathrm{Cd}($ II $)>\mathrm{Co}($ II $)=\mathrm{Ni}($ II $)=\mathrm{Cu}($ II $)>\mathrm{Zn}$ (II) $>\mathrm{Pb}$ (II) with mid point cytotoxicity values (EC50) of $1.4 \cdot 10^{-4} \mathrm{M}, 2.8 \cdot 10^{-4} \mathrm{M}$. $2.9 \cdot 10^{-4} \mathrm{M}, 3.2 \cdot 10^{-4} \mathrm{M} .7 .2 \cdot 10^{-4} \mathrm{M}$, and $2.6 \cdot 10^{-3} \mathrm{M}$, respectively. $\mathrm{Cu}(\mathrm{II})$ tended to increase NR uptake at subcytotoxic concentrations at $10^{-4} \mathrm{M}$.

The relative amount of CYPIA protein was determined in the ELISA assay and compared to the CYPIA amounts induced by 3-MC alone (Figure 2). At concentrations higher than $10^{\circ} \mathrm{M}$. the metals led to a concentration-dependent decrease of CYPIA protein content with the sequence $\mathrm{Cd}(\mathrm{II})>\mathrm{Ni}(\mathrm{II})=$ $\mathrm{Cu}($ II $)=\mathrm{Co}$ (II) $>\mathrm{Zn}$ (II) $>\mathrm{Pb}$ (II). The respective $\mathrm{EC} 50$ values were $5.3 \cdot 10^{5} \mathrm{M}, 2.5 \cdot 10^{+} \mathrm{M}, 3.0 \cdot 10^{+} \mathrm{M}, 3.2 \cdot 10^{+} \mathrm{M}$. $7.8 \cdot 10^{+} \mathrm{M}$, and $2.9 \cdot 10^{-1} \mathrm{M}$. In the case of $\mathrm{Pb}(\mathrm{II})$, an increase of CYP1A protein content at $10{ }^{3} \mathrm{M}$ and $5 \cdot 10^{3} \mathrm{M}$ was detected.

As observed in an earlier study (Brüschweiler et al. 1996b). EROD activities between 35 and $45 \mathrm{pmol} / \mathrm{min} / \mathrm{mg}$ protein were measured, when cells were exposed to $3-\mathrm{MC}\left(5 \cdot 10^{-6} \mathrm{M}\right)$ alone for $3 \mathrm{~d}$. For standardizing the inhibitory effects by the metals. the concurrent control value was set to $100 \%$. The most sensitive effect was observed for $\mathrm{Cd}(\mathrm{II})\left(\mathrm{EC} 50=2.2 \cdot 10^{-5} \mathrm{M}\right)$ followed by $\mathrm{Ni}(\mathrm{II}) \quad\left(8.1 \cdot 10^{-5} \mathrm{M}\right), \mathrm{Cu}(\mathrm{II})\left(1.6 \cdot 10^{-4} \mathrm{M}\right), \mathrm{Co}(\mathrm{II})$ $\left(2.0 \cdot 10^{-4} \mathrm{M}\right), \mathrm{Zn}(\mathrm{II})\left(2.3 \cdot 10^{-4} \mathrm{M}\right)$, and $\mathrm{Pb}$ (II) $\left(8.0 \cdot 10^{-4} \mathrm{M}\right)$ (Figure 3). Contrary to the other metals, a slow decrease of EROD activity for $\mathrm{Pb}(\mathrm{II})$ has been found showing a statistically significant inhibitory effect at $5 \cdot 10^{\circ} \mathrm{M}$.

\section{Effects of Metals on CYPIA-Induced Cell Lysate}

In addition to the previous experiments, interactions of the metals with cytochrome P450 were investigated in lysed cells. Cells, which had been induced by 3-MC and thereafter frozen. were exposed to the metal ions for $15 \mathrm{~min}$. The EROD activity was inhibited in a concentration-dependent manner (Figure 4). An EC50 value was found for $\mathrm{Cd}(\mathrm{II})$ at $8.2 \cdot 10^{-\mathrm{h}} \mathrm{M}$. for $\mathrm{Cu}(\mathrm{II})$ at $1.3 \cdot 10^{\circ} \mathrm{M}$, and for $\mathrm{Co}(\mathrm{II})$ at $8.2 \cdot 10^{-\dagger} \mathrm{M}$. In contrast to $\mathrm{Cd}(\mathrm{II})$ and $\mathrm{Cu}(\mathrm{II})$, the EROD activity decreased slowly with the $\mathrm{Co}(\mathrm{II}) \mathrm{Ni}(\mathrm{II})$, and $\mathrm{Pb}$ (II) concentrations. The solubility of $\mathrm{Ni}(\mathrm{II})$ and $\mathrm{Pb}(\mathrm{II})$ was limited at approximately $7 \cdot 10^{+} \mathrm{M}$ in Tris, where EROD activity was about $60 \%$ of the control value in both cases. For that reason. no EC50 was determined for $\mathrm{Ni}(\mathrm{II})$ and $\mathrm{Pb}(\mathrm{II})$. No effects were observed for $\mathrm{Zn}$ (II) at concentrations up to $6.7 \cdot 10^{\prime} \mathrm{M}$. 


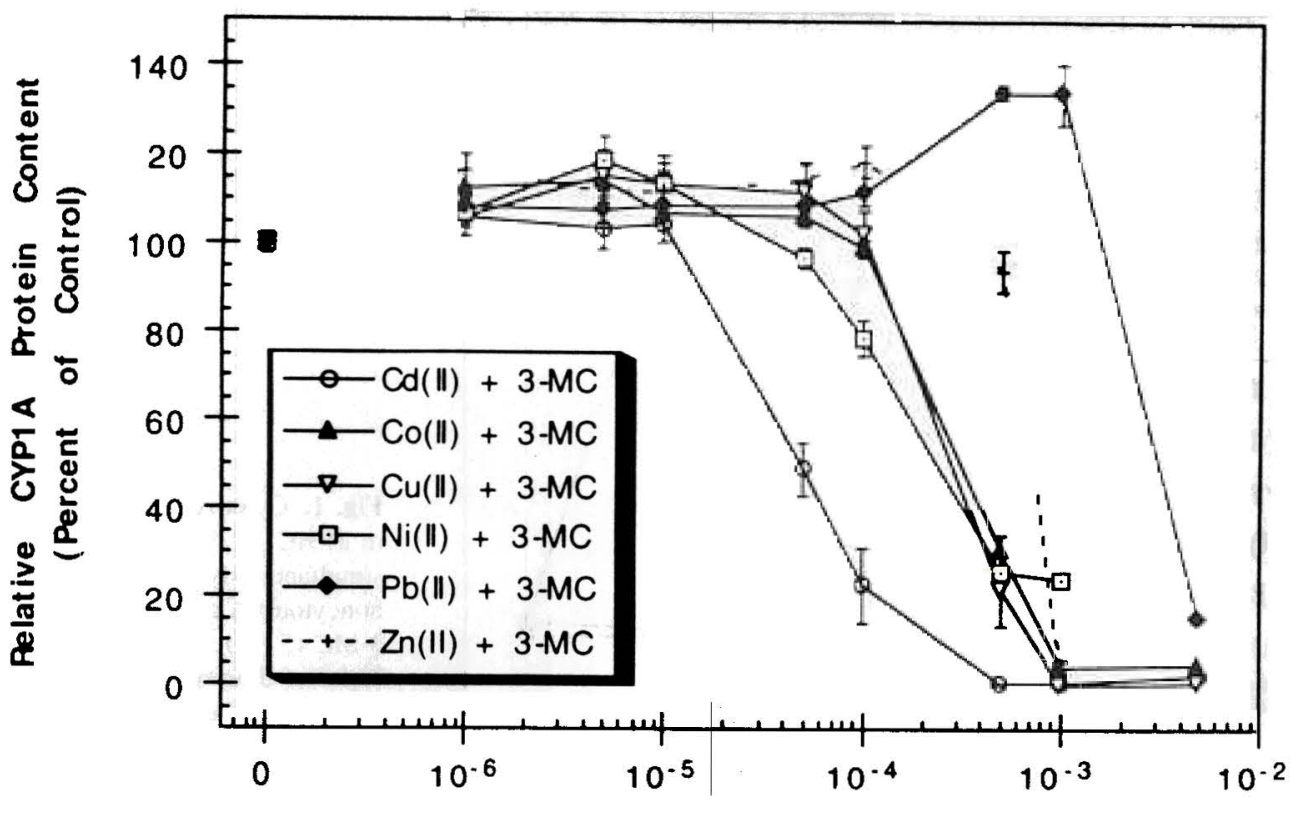

Concentration $[\mathrm{M}]$
Fig. 2. Concentration-response curves of metals on relative CYPIA protein content determined by ELISA. PLHC-1 cells were simultaneously exposed to $3-\mathrm{MC}\left(5 \cdot 10^{\circ} \mathrm{M}\right)$ and a series of diluiions of metals for $3 \mathrm{~d}$. CYPIA amount is expressed as precent of control value. Data are shown as mean percentage of control \pm S.E.M. (six valu. .,

\section{Comparison of EROD Activity, Relative CYPIA Protein Content and Cytotoxicity}

A comparison of the EC50 values of the metals obtained in the different assays is shown in Figure 5. Apart from $\mathrm{Cd}$ (II), the cytotoxic effect and a decrease of CYPIA protein content occurred at the same concentration. The inhibition of EROD activity was the most sensitive reaction in all cases. This indicates that heavy metals inhibit the CYPIA activity prior to affecting the CYPlA protein and causing cytotoxicity. Inhibitory concentrations of $\mathrm{Cd}$ (II) and $\mathrm{Cu}$ (II) on EROD activity were significantly lower after $15 \mathrm{~min}$ than after a 3 -d exposure $(2.7$ times and 12.3 times, respectively). In contrast. $\mathrm{Co}(\mathrm{II})$ inhibited CYPIA enzyme activity at a 4.1 times higher concentration after 15 min than after $3 \mathrm{~d}$, suggesting that heme metabolism is likely the most sensitive target for this metal.

For $\mathrm{Cd}(\mathrm{II})$, differences between the effect concentrations measured in the four assays were most obvious. The reaction as determined by the EC50 value obtained in the EROD assay after $15 \mathrm{~min}$ exposure of the cell lysate was 2.7 times more sensitive than after 3-d simultaneous exposure in living cells, 6.4 times more sensitive than the EC50 measured in the ELISA. and 16.8 times more sensitive than the EC50 measured in the $\mathrm{NR}$ assay. Interestingly, $\mathrm{Pb}(\mathrm{II})$ showed striking differences in the shape of the concentration-response curves between the assays. In contrast to a slow decrease of the EROD activity starting at $5 \cdot 10^{\circ} \mathrm{M}$ in both EROD assays (Figures 3, 4), an increase of the relative CYPIA protein content at $10^{-3} \mathrm{M}$ and $5 \cdot 10^{3} \mathrm{M}$ was found in the ELISA (Figure 2).

\section{Discussion}

Simultaneous treatment of PLHC-1 cells with 3-MC. a CYPIAinducer, and varicus heavy metals for $3 \mathrm{~d}$ resulted in a concentration-dependent inhibition of CYPIA activity. reduction of relative CYPIA protein content and cytotoxicity. Induction of CYP1A protein and activity in the presence of both an inducer (3-MC) and low concentration of inhibitors (heavy metals) has been observed. Therefore, heavy metals seem not to interfere with the binding of the inducer to the aryl hydrocarbon (Ah) receptor, but act at the CYPIA protein L vel. The EC50 values in the assays were between $10^{-5}$ and $10^{-3} \mathrm{M}$, which are at significantly higher concentrations than those measured for trisubstituted and disubstituted organotins in a previous study (Brüschweiler et al. 1996a). All metals were found to affect EROD activity at significantly lower concentrations than the relative CYPIA protein content, whereby $\mathrm{Cd}(\mathrm{II})$ was most active $\left(\mathrm{EC} 50=2.2 \cdot 10^{-5} \mathrm{M}\right)$. Preliminary immunological studies in fish indicated that the inhibition of CYPIA by $\mathrm{Cd}(\mathrm{II})$ is due to a decrease in CYPIA protein rather than a direct inhibition of the enzyme activity (George 1989). In the present study. however. Cd(II) affected EROD activity at a significantly lower concentration $\left(E C 50=2.2 \cdot 10^{-5} \mathrm{M}\right)$ than the relative CYPIA protein content $\left(\mathrm{EC50}=5.3 \cdot 10^{-5} \mathrm{M}\right)$. Reasons for these differences are not known.

Short-term treatment of cell lysate with $\mathrm{Cd}(\mathrm{II})$ and $\mathrm{Cu}(\mathrm{II})$ led to an inhibition of EROD activity at even lower concentrations than in the 3-d experiment. Inhibitory concentrations in the present study coincide with those from a study with mammalian microsomes, in which a direct inhibition of benzolalpyrene hydroxylase has been found at low Cd(II) concentrations of $10^{\circ} \mathrm{M}$ and higher (Fukuhara and Takabatake 1982). Two reasons may account for the higher sensitivity of the cell lysate compared to the cultured living cells. First, in the experiment with cell lysate. the buffer does not contain any serum that may bind free metal ions, which are the most biologically active species. Second, experiments in vivo in fish and in vitro in trout hepatoma cells have shown that $\mathrm{Cd}$ (II), $\mathrm{Cu}$ (II) and $\mathrm{Zn}$ (II) induce metallothionein B. which is capable of sequestering metal ions by binding via thiolate bonds of cysteine residues (Zafarullah ef al. 1989). In contrast to the other metals tested. Co(II) affected 


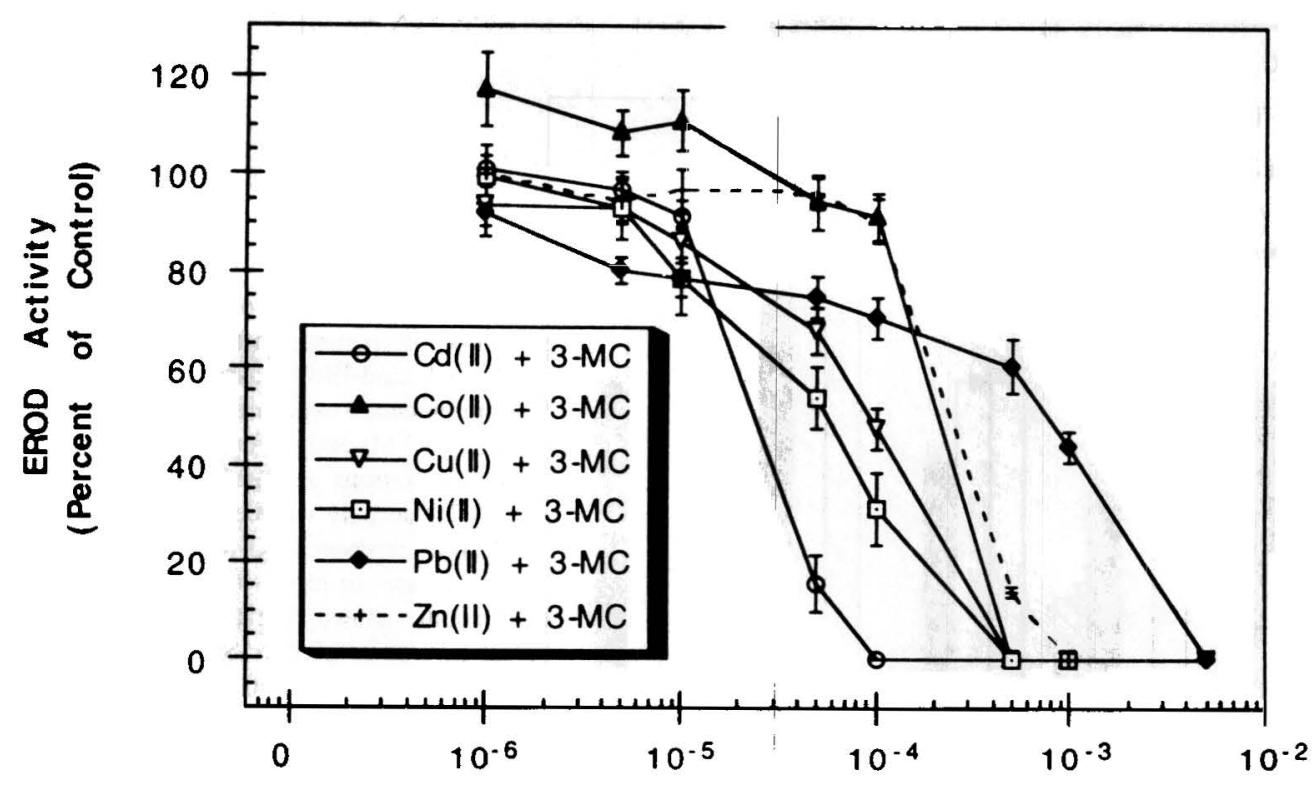

Concentration [M]

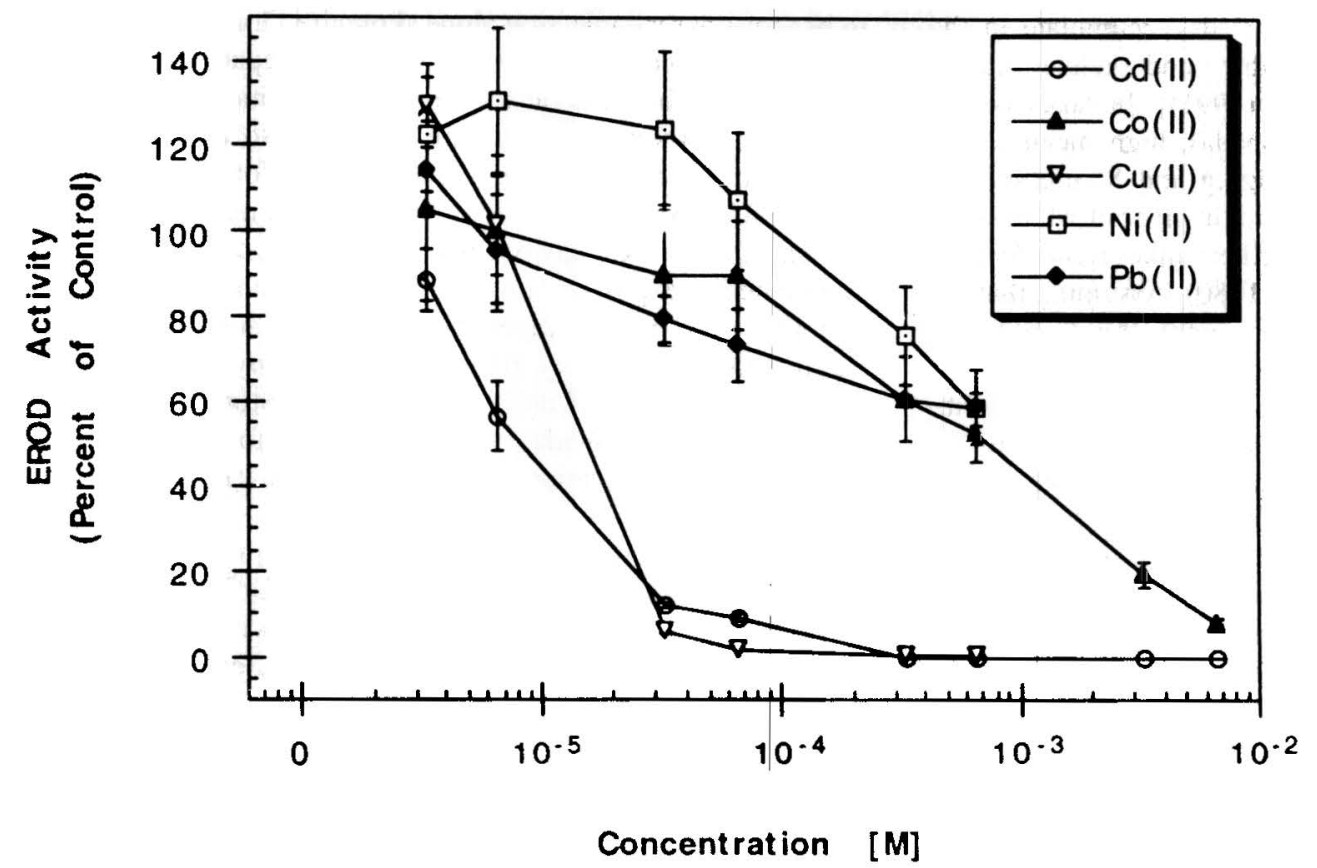

Fig. 3. Concentration-response curves of metals on EROD activity. PLHC- 1 cells were simultaneously exposed to 3-MC $\left(5 \cdot 10^{-6} \mathrm{M}\right)$ and different concentrations of metals for $3 \mathrm{~d}$. Data are shown as mean percentage of control \pm S.E.M. (six values)
Fig. 4. Effects of metals on EROD activity on lysates of 3MC-induced cells. Cells were exposed to $3-\mathrm{MC}\left(5 \cdot 10^{-h} \mathrm{M}\right)$ for $3 \mathrm{~d}$, frozen, and exposed to a series of dilutions of metals for 15 min after thawing. Data are shown as mean of percentage of control \pm S.E.M. (three values). No effects were observed for $\mathrm{Zn}$ (II) up to $6.7 \cdot 10^{\prime} \mathrm{M}$ (curve not shown)
CYPIA enzyme activity in cell lysate less than in living cells. These findings suggest that Co(II) may disturb CYPI A enzyme activity rather in an indirect fashion. probably by inhibition of heme biosynthesis and/or induction of heme oxygenase.

Apart from Cd(II), relative CYPIA protein content was only decreased at cytotoxic concentrations of the heavy metals. Similar effects have been observed for organotins, particularly for dibutyltin, at even lower concentrations in PLHC-1 cells (Brüschweiler et al. 1996a). Thereby, the EC50 in the EROD assay was at $1.2 \cdot 10^{-h} \mathrm{M}$. while those in the ELISA and NR assay were in the same concentration range $\left(9.0 \cdot 10^{\circ} \mathrm{M}\right.$ and $8.7 \cdot 10^{-h} \mathrm{M}$, respectively). These results give support for
CYPIA immunodetection as complementary method to the EROD assay. In case of Cd(II), also a higher susceptibility of the relative CYPIA protein content than in the cytotoxicity was observed. It can be concluded that in addition to the direct effects on EROD activity. indirect effects of Cd(II) resulting in the decrease of CYPIA protein have also to be taken into consideration. Thereby, the interference of $\mathrm{Cd}(\mathrm{II})$ with heme metabolism via induction of heme oxygenase may be most probable.

Whole-body metal levels found in marine fish are in the range of $0.03-4.2 \mathrm{mg} / \mathrm{kg}$ (dry weight) for $\mathrm{Cd}(\mathrm{II}), 0.07-1.45 \mathrm{mg} /$ $\mathrm{kg}$ for $\mathrm{Co}(1 \mathrm{II}$ ), and 2-42 mg/kg for Cu(II) (Depledge et al. 1994). 


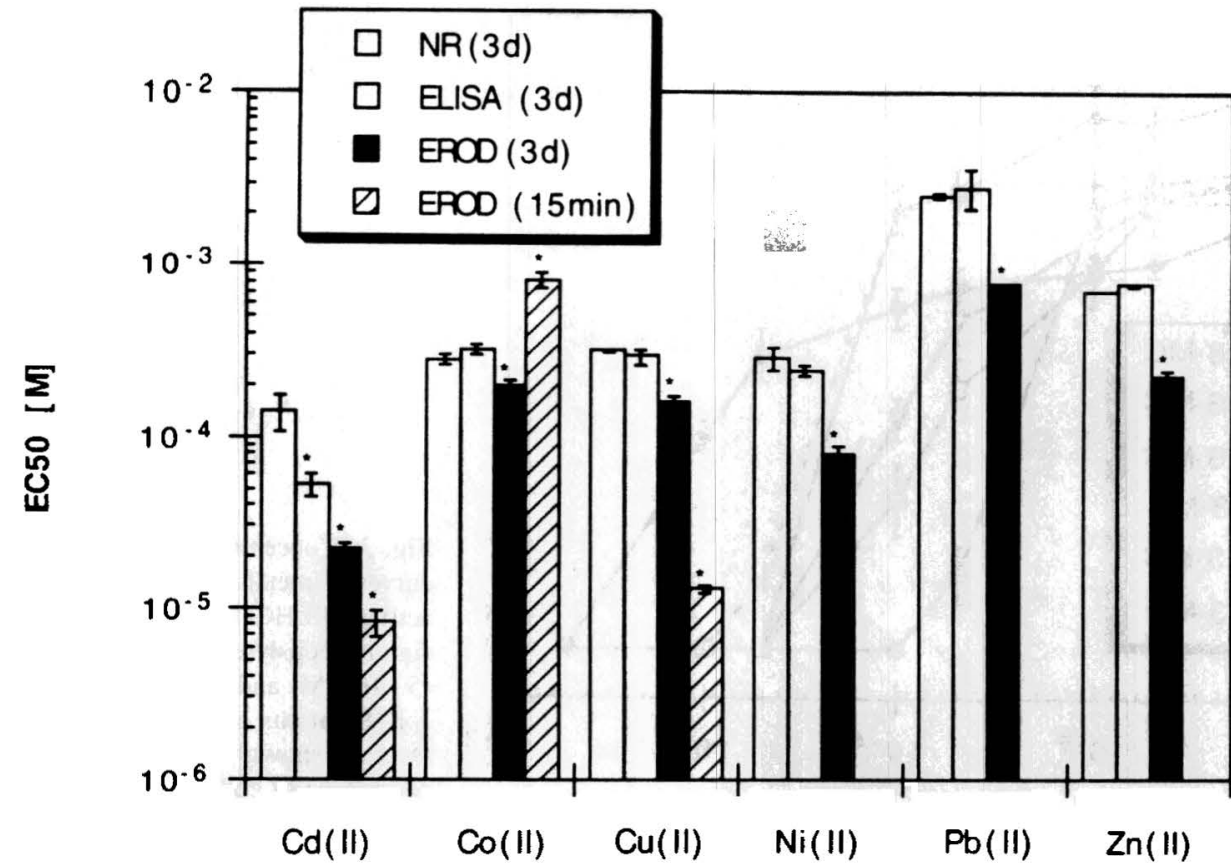

Fig. 5. Comparison of the EC50 values determined in the NR assay. ELISA, and EROD assay after 3-d simultaneous exposure to 3-MC $\left(5 \cdot 10^{-h} \mathrm{M}\right)$ and different concentrations of metals. Additionally. EROD activity was determined after a 15 min exposure of 3-MC-induced cell lysates to metals (EROD $15 \mathrm{~min}$ ). Data are shown as mean of percentage of control \pm S.E.M. *Significantly different from the left neighboring bar at $p<0.05$. No effects were measured for $\mathrm{Ni}(\mathrm{II}), \mathrm{Pb}(\mathrm{II})$, and $\mathrm{Zn}$ (II) due to their limited solubility: for that reason, no bars for these metals are shown
$\mathrm{Cd}(\mathrm{II})$ and $\mathrm{Cu}$ (II) are known to primarily accumulate in the liver and to a lesser extent in the kidney and skeletal muscle of fish [for overview, see Sorensen (1991)]. In lakes near a base metal smelter at Flin Flon (Canada), high mean Cd(II) and $\mathrm{Cu}(\mathrm{II})$ concentrations of $10.1 \mathrm{mg} / \mathrm{kg}$ and $84 \mathrm{mg} / \mathrm{kg}$ (dry weight), respectively, were measured in the liver of white suckers (Catostomus commersoni) and northern pikes (Esox lucius), respectively (McFarlane and Franzin 1980). Assuming that the liver dry weight is $20 \%$ of the fresh weight, this would give $\mathrm{Cd}$ (II) and $\mathrm{Cu}(\mathrm{II})$ concentrations in the liver of $1.8 \cdot 10^{-5} \mathrm{M}$ and $2.6 \cdot 10^{-4} \mathrm{M}$, respectively. This is in the range of the inhibitory effects on the EROD activity measured in the present study after 3-d exposure in living fish hepatoma cells $\left(\mathrm{EC50}(\mathrm{Cd}(\mathrm{II}))=2.2 \cdot 10^{-5} \mathrm{M}, \mathrm{EC50}(\mathrm{Cu}(\mathrm{II}))=1.6 \cdot 10^{-4} \mathrm{M}\right)$. Mean $\mathrm{Cd}(\mathrm{II}), \mathrm{Co}$ (II) and $\mathrm{Cu}(\mathrm{II})$ levels in fish would however be below these effect concentrations. The comparison of the environmental tissue concentrations in fish and the effects measured in vitro underscores the environmental relevance of the possible inhibitory activity of metals on the CYPIA system at highly polluted sites.

In vivo experiments in fish have shown that the influence of heavy metals on CYPIA induction response is complex. Inhibition of EROD and benzo[ $a]$ pyrene hydroxylase activity has been found after intraperitoneal co-injection of $\mathrm{Cd}(\mathrm{II})$ ( 1 and $1.4 \mathrm{mg} / \mathrm{kg}$ body weight) and a CYP1A-inducer in plaice (Pleuronectes platessa) (George and Young 1986). and in black sea bass (Centropistis striata) (Fair 1986) after 2-d exposure. No changes in the liver cytochrome P450 monooxygenase activities, a slightly elevated liver cytochrome P450 content, and even a marked increase of 7-ethoxycoumarin- $O$-deethylase activity in the kidney have been observed after four weeks exposure of rainbow trout to sublethal aqueous $\mathrm{Cd}(\mathrm{II})$ concentration ( $100 \mu \mathrm{g} / \mathrm{L}$ ) compared to the control without $\mathrm{Cd}(\mathrm{II})$ preexposure (Förlin et al. 1986). Even a doubling of the benzo[a|pyrene hydroxylase activity and microsomal cytochrome $\mathbf{P} 450$ protein content have bien measured, when eels Anguilla anguilla were exposed to Cd-containing ( $5 \mu \mathrm{g} / \mathrm{L}$ ) seawater for $24 \mathrm{~d}$ following a benzol $a$ |pyrene injection ( $20 \mathrm{mg} / \mathrm{kg}$ body weight). compared to benzo| $a \mid$ pyrene injection alone (Lemaire-Gony and Lemaire 1992). Tolerance development of $\mathrm{Cd}$ (II) on hepatic drug oxidation has been shown in rats, whereby metallothionein induction and other unknown factors were suggested to be responsible for this tolerance phenomenon. The reasons for the enhancing effect of $\mathrm{Cd}(\mathrm{II})$ on the CYPIA induction response in eel remain unclear. Differences may occur among species, after short-term simultaneous exposure and long-term preexposure of $\mathrm{Cd}(\mathrm{II})$, and after uptake via intraperitoneal injection and via contaminated water. Modulatory effects on CYPIA by heavy metals. especially $\mathrm{Cd}(\mathrm{II})$ and $\mathrm{Cu}(\mathrm{II})$, have to be investigated in further studies in order to elucidate their significance for indirect toxicity and for the application of CYPIA as biomarker in environmental monitoring.

Cytotoxicity in terms of EC50 values of the mixture of metals and 3-MC were found between $1.4 \cdot 10^{-4} \mathrm{M}$ (for $\mathrm{Cd}(\mathrm{II})$ ) and $2.6 \cdot 10^{-3}$ (for $\mathrm{Pb}(\mathrm{II})$ ). This is in accordance with other in vitro studies, in which fish cell lines have been used and exposed to the metals alone (Babich et al. 1986; Segner and Lenz 1993; Ryan and Hightower 1994). With mammalian cells in vitro, the following biochemical targets are primarily involved in heavy metal cytotoxicity. $\mathrm{Cd}(\mathrm{II})$ and other heavy metals such as $\mathrm{Hg}$ (II), $\mathrm{Cu}$ (II), and $\mathrm{Zn}$ (II) are known to bind to $\mathrm{Ca}^{2}$ channels, $\mathrm{Ca}^{2} \%$ $\mathrm{Mg}^{2-}$-ATPase, and calmodulin leading to the disruption of $\mathrm{Ca}^{2}$ homeostasis and following loss of cell viability [for review, see Viarengo and Nicotera (1991)]. Other important enzymatic and structural SH-containing proteins, such as $\mathrm{Na} / \mathrm{K}^{-}$-ATPase. DNA- and RNA-polymerase, tubulin, and actin are affected by Cd(II) interactions (Viarengo and Nicotera 1991). Determination of the most sensitive and relevant biochemical targets in heavy metal cytotoxicity awaits further experimental evaluation in vitro and in vivo.

\section{Conclusions}

Inhibitory effects of heavy metals on the cytochrome P4501 A induction in fish hepatoma cells PLHC-I were analyzed. During 
the induction response in living cells. the EROD activity was more strongly affected by metals than the relative CYPIA protein content indicating a direct inactivation of CYPIA catalytic activity. These findings are corroborated by the inhibitory concentrations of $\mathrm{Cd}(\mathrm{II})$ and $\mathrm{Cu}(\mathrm{II})$ on EROD activity. which are significantly lower in the experiments with cell lysate than in those with cultured living cells. Effects on CYPIA protein synthesis and heme metabolism are less sensitive than enzyme activity after the 3-d exposure. The results lead to the conclusion that $\mathrm{Cd}(\mathrm{II})$ and $\mathrm{Cu}$ (II) with their higher potential to affect CYPIA enzyme activity than other metals have to be taken into consideration in CYPIA biomarker monitoring. This is of special importance, because $\mathrm{Cd}(\mathrm{II})$ and $\mathrm{Cu}(\mathrm{II})$ are widespread environmental pollutants. The modulating effect of heavy metals on CYPIA corroborate previous findings with organotins (Fent and Stegeman 1993; Fent and Bucheli 1994; Fent 1996; Brüschweiler et al. 1996), thus underscoring the inclusion of additional environmental pollutants in the interpretation of biomarker findings. Since the CYP1A protein level is less susceptible than enzyme activity to inhibitory actions of environmental pollutants (such as heavy metals and organotins) during ( CP1A induction response, CYPIA biomarker monitoring shou!:! be relied on both measures (Bucheli and Fer. 1995).

Acknowledgments. We thank L.E. Hightower (University of Connecticut, USA) for providing the PLHC-1 cells, J.J. Stegeman (Woods Hole Oceanographic Institution, USA) for the antibody 1-12-3, and L. Sigg (EAWAG) for reading the manuscript. This work was supported by a grant from the Stiftung Forschung 3R, Bern. Switzerland, Grant No. 40/92 to K. Fent.

\section{References}

Alvares AP. Leigh S, Cohn J, Kappas A (1972) Lead and methyl mercury: effects of acute exposure on cytochrome P-450 and the mixed function oxidase system in the liver. J Exp Med 135: 1406-1409

Babich H. Shopsis C. Borenfreund E (1986) In vitro cytotoxicity testing of aquatic pollutants (cadmium, copper. zinc, nickel) using established fish cell lines. Ecotoxicol Environ Saf 11:91-99

Brüschweiler BJ. Würgler FE. Fent K (1995) Cytotoxicity in vitro of organotin compounds to fish hepatoma cells PLHC-1 (Poeciliopsis lucida). Aquat Toxicol 32:143-160

(1996a) Inhibition of cytochrome P4501A by organotins in fish hepatoma cells PLHC-1. Environ Toxicol Chem 15:728-735

(1996b) An ELISA assay for cytochrome P4501 in fish liver cells. Environ Toxicol Chem 15:592-596

Bucheli TD, Fent K (1995) Induction of cytochrome P450 as a biomarker for environmental contamination in aquatic ecosystems. Crit Rev Environ Sci Technol 25:201-268

De Matteis F (1978) Loss of liver cytochrome P-450 caused by chemicals. In: De Matteis F. Aldrigde WN (ed), Heme and hemeproteins, Handbook of exp pharmacol, Vol 44. Springer-Verlag. Berlin, pp 95-127

Degawa M. Arai H, Miura S, Hashimoto Y (1993a) Preferential inhibitions of hepatic P450IA2 expression and induction by lead nitrate in the rat. Carcinogenesis 14:1091-1094

Degawa M. Arai H. Kubota M. Hashimoto Y (1993b) lonic lead. a unique metal ion as an inhibitor for cytochrome P4501A? (CYPIA2) expression in the rat liver. Biochem Biophys Res Commun 200:1086-1092

Depledge MH. Weeks JM. Bjerregaard P (1994) Heavy metuls. In:
Calow $\mathbf{P}$ (ed). Handbook of ecotoxicology, Blackwell Scientific Publications. Oxford, pp 79-105

Fair PH (1986) Interaction of benzo(a)pyrene and cadmium on GSHS-transferase and benzo(a)pyrene hydroxylase in the black sea bass Centropristis striata. Arch Environ Contamin Toxicol 15:257-263

Fent K (1996) Ecotoxicology of organotin compounds. Crit Rev Toxicol 26: 1-117

Fent K. Bucheli TD (1994) Inhibition of hepatic microsomal monooxygenase system by organotins in vitro in freshwater fish. Aquat Toxicol 24:107-126

Fent K. Stegeman JJ (1993) Effects of tributyltin in viro on hepatic cytochrome P450 forms in marine fish. Aquat Toxicol 24:219-240

Förlin L. Haux C. Karlsson-Norrgren L. Runn P. Larsson A (1986) Biotransformation enzyme activities and histopathology in rainbow trout. Salmo gairdneri, treated with cadmium. Aquat Toxicol 8:5i-64

Fukuhara M. Takabatake E (1982) In vitro action of cadmium on microsomal monooxygenase of rabbit lung. Biochem Pharmacol $31: 3425-3429$

George SG (1989) Cadmium effects on plaice liver xenobiotic and metal detoxication systems: dose-response. Aquat Toxicol 15:303-310

George SG. Young P (1986) The time course of effects of cadmium and 3-methylcholanthrene on activities of enzymes of xenobiotic metabolism and metaltothionein levels in the plaice. Pleuronectes platessa. Comp Biochem Physiol 83C:37-44

Goering PL (1993) Lead-protein interactions as a basis for lead toxicity. Neurotoxicology 14:45-60

Hadley WM. Miya TS. Bousquet WF (1974) Cadmium inhibition of hepatic drug metabolism in the rat. Toxicol Appl Pharmacol 28:284-291

Hahn ME, Lamb TM. Schultz ME. Smolowitz RM. Stegeman JJ (1993) Cytochrome P4501A induction and inhibition by $3.3^{\prime}, 4.4^{\prime}$-tetrachlorobiphenyl in an Ah receptor-containing fish hepatoma cell line (PLHC-1). Aquat Toxicol 26:185-208

Hightower LE. Renfro JL (1988) Recent applications of fish cell culture to biomedical research. J Exp Zool 248:290-302

Lemaire-Gony S. Lemaire P (1992) Interactive effects of cadmium and benzo(a)pyrene on cellular structure and biotransformation enzymes of the liver of the European eel Anguilla anguilla. Aquat Toxicol 22:145-160

Maines MD, Kappas A (1977) Metals as regulators of heme metabolism. Science 198:1215-1221

Mance $G$ (1987) Pollution threat of heavy metals in aquatic environments. Elsevier. London. pp 1-372

McFarlane GA. Franzin WG (1980) An examination of $\mathrm{Cd}$. $\mathrm{Cu}$. and $\mathrm{Hg}$ concentrations in livers of northern pike. Esox lucius, and white sucker. Catostomus commersoni. from five lakes near a base metal smelter at Flin Flon. Manitoba. Can J Fish Aquat Sci 37:1573-1578

Ryan JA. Hightower LE (1994) Evaluation of heavy metal ion toxicity in fish cells using a combined stress and cytotoxicity assay. Environ Toxicol Chem 13:123!-1240

Sassa $S$ (1978) Toxic effects of lead. with particular reference to porphyrin and heme metabolism. In: DeMatteis F. Aldridge WN (ed). Heme and hemeproteins. Handbook exp pharmacol. Vol +4 . Springer-Verlag. Berlin. pp 333-371

Segner H. Lenz D (1993) Cytotoxicity assays with the rainbow trout RI cell line. Toxicol in Vitro 7:537-540

Sorensen EM (1991) Metal poisoning in fish. CRC Press, Boca Raton. FL. pp 1-374

Stegeman JJ. Hahn ME (1994) Biochemistry and molecular biology of monooxygenase: current perspectives on forms, functions, and regulation of cytochrome $\mathbf{P 4 5 0}$ in aquatic species. In: Malins DC, Ostrander GK (ed). Aquatic toxicology. Lewis Publishers. Boca Raton FL. pp 87-206

Tephly TR (1978) Inhibiuon of $i$ ver hemoprotein synthesis. In: De Matteis F. Aldrigde WN (ed). Heme and hemeproteins. Handbook exp pharmacol. Vol 44. Springer-Verlag. Berlin. pp 81-94

Tillitt DE. Giesy JP. Ankley GT (1991) Characterization of the H4IIE 
rat hepatoud cell bioassay as a tool for assessing toxic potency of planar halogenated hydrocarbons in environmental samples. Environ Sci Technol 25:87-92

Viarengo A (1989) Heavy metals in marine invertebrates: mechanisms of regulation and toxicity at the cellular level. Aquatic Sciences 1:295-317
Viarengo A. Nicotera $\mathrm{P}$ (1991) Possible role of $\mathrm{Ca}^{2+}$ in heavy metal cytotoxicity. Comp Biochem Physiol 100C: 81-84

Zafarullah M. Olsson P-E. Gedamu L (1989) Endogenous and heavymetal-ion-induced metallothionein gene expression in salmonid tissues and cell lines. Gene 83:85-93 